\title{
Waiting times, patient flow, and occupancy density in South African primary health care clinics: implications for infection prevention and control
}

Aaron S Karat ${ }^{1,2}$, Nicky McCreesh ${ }^{1}$, Kathy Baisley ${ }^{1,3}$, Indira Govender ${ }^{1}$, Idriss I Kallon ${ }^{4,5}$, Karina Kielmann ${ }^{2}$, Hayley MacGregor ${ }^{6}$, Anna Vassall ${ }^{1}$, Tom A Yates ${ }^{7}$, Alison D Grant ${ }^{1,3,8}$

\section{Affiliations}

1. TB Centre, London School of Hygiene \& Tropical Medicine, London, United Kingdom

2. The Institute for Global Health and Development, Queen Margaret University, Edinburgh, United Kingdom

3. Africa Health Research Institute, School of Laboratory Medicine \& Medical Sciences, College of Health Sciences, University of KwaZulu-Natal, Durban, South Africa

4. Division of Social and Behavioural Sciences, Faculty of Health Sciences, University of Cape Town, Cape Town, South Africa

5. Centre for Evidence-based Health Care, Division of Epidemiology and Biostatistics, Department of Global Health, Faculty of Medicine and Health Sciences, Stellenbosch University, Cape Town, South Africa

6. The Institute of Development Studies, University of Sussex, Brighton, United Kingdom

7. Department of Infectious Disease, Faculty of Medicine, Imperial College London, London, United Kingdom

8. School of Public Health, Faculty of Health Sciences, University of the Witwatersrand, Johannesburg, South Africa

\section{Corresponding author}

Dr Aaron Karat, Department of Clinical Research, Faculty of Infectious and Tropical Diseases, London School of Hygiene \& Tropical Medicine, Keppel Street, London WC1E 7HT, United Kingdom

Tel: +44 (0)2076368636 | Email: aaron.s.karat@gmail.com 
medRxiv preprint doi: https://doi.org/10.1101/2021.07.21.21260806; this version posted July 23,2021 . The copyright holder for this preprint (which was not certified by peer review) is the author/funder, who has granted medRxiv a license to display the preprint in perpetuity.

It is made available under a CC-BY 4.0 International license .

\section{Abstract}

\section{Background}

3 Transmission of respiratory pathogens, such as Mycobacterium tuberculosis and severe acute respiratory

4 syndrome coronavirus 2, is more likely during close, prolonged contact and when sharing a poorly ventilated

5 space. In clinics in KwaZulu-Natal (KZN) and Western Cape (WC), South Africa, we estimated clinic visit

6 duration, time spent indoors and outdoors, and occupancy density of waiting rooms.

\section{Methods}

8 We used unique barcodes to track attendees' movements in 11 clinics in two provinces, multiple imputation

9 to estimate missing arrival and departure times, and mixed-effects linear regression to examine associations

10 with visit duration.

\section{Results}

122,903 attendees were included. Median visit duration was 2 hours 36 minutes (interquartile range [IQR]

13 01:36-3:43). Longer mean visit times were associated with being female (13.5 minutes longer than males;

$14 \mathrm{p}<0.001)$ and attending with a baby (18.8 minutes longer than those without; $p<0.01)$, and shorter mean

15 times with later arrival (14.9 minutes shorter per hour after $0700 ; p<0.001)$ and attendance for tuberculosis

16 or ante/postnatal care (24.8 and 32.6 minutes shorter, respectively, than HIV/acute care; $p<0.01$ ).

17 Overall, attendees spent more of their time indoors (median 95.6\% [IQR 46-100]) than outdoors (2.5\% [IQR

18 0-35]). Attendees at clinics with outdoor waiting areas spent a greater proportion (median 13.7\% [IQR 1-

19 75]) of their time outdoors.

20 In two clinics in KZN (no appointment system), occupancy densities of $\sim 2.0$ persons $/ \mathrm{m}^{2}$ were observed in

21 smaller waiting rooms during busy periods. In one clinic in WC (appointment system), occupancy density did

22 not exceed 1.0 persons $/ \mathrm{m}^{2}$ despite higher overall attendance. 
medRxiv preprint doi: https://doi.org/10.1101/2021.07.21.21260806; this version posted July 23,2021 . The copyright holder for this preprint (which was not certified by peer review) is the author/funder, who has granted medRxiv a license to display the preprint in perpetuity.

It is made available under a CC-BY 4.0 International license.

\section{Conclusions}

24 Longer waiting times were associated with early arrival, being female, and attending with a young child.

25 Attendees generally waited where they were asked to. Regular estimation of occupancy density (as patient

26 flow proxy) may help staff assess for risk of infection transmission and guide intervention to reduce time

27 spent in risky spaces.

28 Key words

29 tuberculosis; SARS-COV-2; COVID-19; transmission; airborne; nosocomial; infection prevention; healthcare-

30 associated infection; health services management 
medRxiv preprint doi: https://doi.org/10.1101/2021.07.21.21260806; this version posted July 23,2021 . The copyright holder for this preprint (which was not certified by peer review) is the author/funder, who has granted medRxiv a license to display the preprint in perpetuity.

It is made available under a CC-BY 4.0 International license .

\section{Background}

Transmission of respiratory infections is a persistent problem in health care facilities, where proportions of attendees who are infectious and susceptible are likely to be higher than in other settings. ${ }^{[1-3]}$ As well as creating risk for individuals attending for care, nosocomial transmission can 'institutionally amplify' epidemics and represents a serious threat to health care worker (HCW) safety. ${ }^{[4-7]}$ Pathogens such as Mycobacterium tuberculosis $(\mathrm{Mtb})^{[8,9]}$ and severe acute respiratory syndrome coronavirus 2 (SARS-CoV$2)^{[10,11]}$ are more likely to be transmitted during close, prolonged contact and between individuals 'sharing

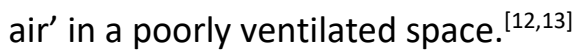

Reducing overcrowding and time spent in health care facilities are recommended infection prevention and control (IPC) measures for tuberculosis (TB) and other respiratory infections. ${ }^{[14,15]}$ Several initiatives to reduce frequency of clinic visits have been tested and deployed, primarily with the intention of providing 'differentiated care'. ${ }^{[16,17]}$ However, interventions that focus on the movement of people around the facility ('patient flow') have received less attention than individual-focused IPC interventions, such as mask-wearing, triage, and prompt initiation of treatment, ${ }^{[18,19]}$ and 'passive' interventions, such as structural changes to improve ventilation. ${ }^{[20]}$ This is partly because of the complexity of intervening to change patient flow or waiting times in busy facilities, which can vary widely in size, layout, internal organisation, and patient load. ${ }^{[21]}$ Considerations also differ for hospitals and primary health care $(\mathrm{PHC})$ clinics; this article relates mainly to operations at PHC level.

\section{Estimating time spent in South African PHC clinics}

The nearly 3,500 PHC clinics in South Africa function in diverse epidemiological, political, cultural, and climactic conditions and serve individuals with a wide range of needs. ${ }^{[22]}$ Long clinic waiting times have been documented over many years ${ }^{[23,24]}$ and are frequently cited as a concern for patients. ${ }^{[25-27]}$ The 'Ideal Clinic' initiative, devised and scaled up by the National Department of Health since 2013, aims to enable universal standards of practice, routine measurement of relevant metrics, and fair comparisons of performance between facilities. ${ }^{[28]}$ Regular estimation of waiting times is recommended by Ideal Clinic and is standard 
medRxiv preprint doi: https://doi.org/10.1101/2021.07.21.21260806; this version posted July 23,2021 . The copyright holder for this preprint (which was not certified by peer review) is the author/funder, who has granted medRxiv a license to display the preprint in perpetuity.

It is made available under a CC-BY 4.0 International license .

practice in most clinics, though the methods used vary by province. National guidelines recommend that

total visit times should be less than three hours. ${ }^{[29]}$

Most approaches to estimating waiting times conceptualise the patient's journey through the clinic as linear,

with each individual passing through the clinic as quickly as possible while ensuring that the necessary 'touch points' are accessed. In South Africa, waiting times are usually measured through the provision of a physical card to all or a selection of patients attending on the day. ${ }^{[30]}$ This card is time-stamped at the beginning and end of each interaction with a service or 'touch point' (for example, when an individual has their blood pressure measured or sees a clinician). This method is useful for estimating time spent waiting for services and the efficiency of selected processes but is less useful in assessing risk of respiratory disease transmission, as it does not describe where patients are waiting. This method also does not include non-patient attendees disease, nor does it allow for estimation of staff exposure to 'high risk' areas.

This work was conducted as part of the Umoya omuhle study, a multidisciplinary initiative taking a 'whole systems' approach to TB IPC in South African PHC clinics. ${ }^{[31]}$ This study component aimed to develop and test a method to 1) estimate how long attendees spent in clinics, and determine why some individuals spent longer than others; 2) estimate how long attendees spend in outdoor and indoor clinic areas; 3) describe variation in occupancy of waiting areas over the clinic day; and 4) collect data for mathematical modelling of IPC interventions in clinics to reduce risk of $M t b$ transmission (McCreesh et al., in preparation).

\section{Methods}

The literature was reviewed to explore methods previously used to estimate waiting times, occupancy density, crowding, and patient flow (Appendix 1). The methods that allowed estimation of the broadest range of outcomes were waiting/working time surveys (either paper-based or using a real-time location system $)^{[23,27,32]}$ and camera-based systems. ${ }^{[33-35]}$ Given the resources available to the study, as well as the 
medRxiv preprint doi: https://doi.org/10.1101/2021.07.21.21260806; this version posted July 23,2021 . The copyright holder for this preprint (which was not certified by peer review) is the author/funder, who has granted medRxiv a license to display the preprint in perpetuity.

It is made available under a CC-BY 4.0 International license .

81 based on waiting time surveys was used. As described below, unique barcodes and hand-held barcode

82 scanners were used instead of radio-frequency identification tags ${ }^{[36-38]}$ or a paper-based system. ${ }^{[30]}$

\section{Data collection}

84 Data were collected in clinics in KwaZulu-Natal (KZN) province (coded KZN1-6) from 22 February to 14

85 March 2019 and in Western Cape (WC) province (coded WC1-6) from 14-22 May 2019. Clinics were visited

86 at least once prior to data collection to provide written information, discuss concerns with managers and

87 staff, and observe patient flow (Supplementary figure 1). On the day of data collection, a member of the

research team attended the morning staff meeting to answer additional questions and issue unique

barcodes to staff (including non-clinical staff). Each HCW who accepted a barcode was asked for their job

title and role that day. No other personal information was collected. Cards were used that could be easily

HCW) to be worn, on a lanyard, around their neck.

Researchers (usually 6-10 individuals, depending on the size of the clinic) were positioned at key points

throughout the premises, including facility entrance(s), the window where patient files were issued (filing

station), the triage/vitals station, and doorways of consultation rooms and waiting areas (Supplementary

figure 3). Each researcher carried a cordless, hand-held barcode scanner (OPN-2001, Opticon Limited, United

Kingdom); clinic staff in certain locations (most often consultation rooms) were also asked to carry scanners

and were instructed on how and when to use them. Scanners were cleaned of all data and time-

synchronised before each day's data collection.

All individuals attending the clinic during the hours of data collection were asked to participate. A researcher 
medRxiv preprint doi: https://doi.org/10.1101/2021.07.21.21260806; this version posted July 23,2021 . The copyright holder for this preprint (which was not certified by peer review) is the author/funder, who has granted medRxiv a license to display the preprint in perpetuity.

It is made available under a CC-BY 4.0 International license .

anonymous. Numbers and details of individuals who refused were not recorded because the enrolment process was time-sensitive. Individuals who agreed to participate were asked to complete the card (recording their sex, age group, and reason for attendance) and to wear the barcode until they left the clinic. If requested, the researcher completed the card on a participant's behalf. Individuals attending together had their cards stapled together before storage; this was accounted for during data entry.

At the beginning of data collection, all individuals already in the clinic were asked to participate and their location noted by use of a designated scanner. Simultaneously, researchers positioned at the entrance(s) asked individuals who were entering the clinic to participate. Within $60-90$ minutes of commencing data collection, all individuals were offered the opportunity to participate; this sometimes took longer for busier clinics.

Barcode scanners at doorways and other designated 'transition points' were used to scan every person with a barcode who passed through. Scanners at filing or vitals stations (where blood pressure and other measurements were taken), consultation rooms, or at other service points were used to scan an individual's arrival and departure from that station or room. Individuals leaving the clinic had their barcode scanned as they left. For logistical reasons, data collection was stopped at 1400; at this point all individuals remaining in the clinic were scanned, with designated scanners used to note their location. A questionnaire was administered to the facility manager or nurse in charge to record information about staffing levels and other factors that may have affected service provision. The dimensions of waiting areas were measured using a Bosch PLR 40R digital laser measure (Bosch, Gerlingen, Germany; accuracy +/-2 mm).

\section{Data management}

Data from barcode scanners were transferred to a password-protected computer at the end of each day's data collection. Data from completed cards were entered into a Research Electronic Data Capture (REDCap) database, ${ }^{[39,40]}$ hosted at the Africa Health Research Institute, that was programmed to assign a 'group ID' to 
medRxiv preprint doi: https://doi.org/10.1101/2021.07.21.21260806; this version posted July 23,2021 . The copyright holder for this preprint (which was not certified by peer review) is the author/funder, who has granted medRxiv a license to display the preprint in perpetuity.

It is made available under a CC-BY 4.0 International license .

\section{Analysis}

131 Analysis had three strands, examining 1) time spent in clinic and factors that influenced this; 2) the all individuals attending together (denoted by cards having been stapled together). Data from questionnaires administered to facility managers were entered into a password-protected Excel spreadsheet. outdoors (lower risk, primarily due to better ventilation), and how this varied by clinic and reason for visit; and 3) in clinics with more than one indoor waiting area, occupancy density of each indoor waiting area and how this varied over the course of the day. Supplementary table 3 describes the clinics and numbers of individuals included in each analysis.

\section{Time spent in clinic}

A large number of data were missing for arrival and departure times because several individuals were already in the clinic when data collection began or remained in the clinic when data collection ended and therefore did not have their arrival and/or departure time recorded. Multiple imputation was used to generate arrival and/or departure times for individuals in whom one or both was not recorded (see Appendix 2.2.1 for details).

Data were excluded from this analysis where clinic entry and exit were not recorded (because the research team was too small to monitor all entrances and exits of the clinic). Using multiply-imputed data ( $n=20$ imputations), relationships between individual characteristics and time spent in clinic (continuous outcome) were examined using a mixed-effects linear regression model with a random effect for clinic. Province was included as fixed effect. The shape of the relationship between time of arrival and time spent in clinic was examined using fractional polynomials regression with a set of defined powers $(-2,-1,-0.5,0.5,1,2$, and $\ln [\mathrm{x}])$ and a maximum of two power terms in the model. The differences in model deviances were compared: the linear model was used if the improvement in fit was not statistically significant at $p<0.05$. Province, age group, sex, and the ratio of patients to clinical staff were included in the multivariable model as a priori 
medRxiv preprint doi: https://doi.org/10.1101/2021.07.21.21260806; this version posted July 23,2021 . The copyright holder for this preprint (which was not certified by peer review) is the author/funder, who has granted medRxiv a license to display the preprint in perpetuity.

It is made available under a CC-BY 4.0 International license .

\section{Ethical considerations}

174 Identifiable data were not collected from participating individuals; written informed consent was not 175 requested. This study received ethical approval from the Biomedical Research Ethics Committee of the

confounders; other variables were included if they showed an important association $(p<0.05)$ in the univariable model. Coefficients, representing the difference in mean time spent in clinic (in minutes), are reported with $95 \%$ confidence intervals (Cls).

\section{Proportion of time spent indoors vs. outdoors}

Non-imputed data were used from clinics where a scanner had been positioned at all facility entrance/s and all indoor/outdoor doorways. Individuals with a total captured visit time of less than five minutes were excluded, as they were considered likely to have discarded their barcode. Each individual's pathway through the clinic was mapped: for each barcode scan recorded, the individual's location in the time preceding the scan was categorised as 'indoors', 'outdoors', or 'unknown' (if they appeared to have moved between two unconnected locations, indicating a missing barcode scan) based on the location of their previous scan. Total time spent in each type of location (as a proportion of the individual's overall recorded time in clinic) was summarised by clinic and by self-reported reason for clinic attendance.

\section{Occupancy density}

Non-imputed data were used from clinics that had more than one indoor waiting area and where a barcode scanner had been positioned at all entrances and exits of at least two waiting areas. Data were divided into 10 second slices and entries and exits from each demarcated space noted for each 10 second period; the number of individuals within a space at the end of each 10 second period was divided by the floor area and volume of that space to give the occupancy density (in persons $/ \mathrm{m}^{2}$ and persons $/ \mathrm{m}^{3}$, respectively) for that 10 second period.

Analyses were conducted in Stata versions 14 and 16 (Statacorp, College Station, Tx). Figures were created using Stata, Microsoft PowerPoint, Microsoft Excel, and Inkscape v0.92.4. ${ }^{[41]}$ 
medRxiv preprint doi: https://doi.org/10.1101/2021.07.21.21260806; this version posted July 23,2021 . The copyright holder for this preprint (which was not certified by peer review) is the author/funder, who has granted medRxiv a license to display the preprint in perpetuity.

It is made available under a CC-BY 4.0 International license .

University of KwaZulu-Natal (ref. BE082/18), the Human Research Ethics Committee of the Faculty of Health

Sciences of the University of Cape Town (ref. 165/2018), the Research Ethics Committee of Queen Margaret University (ref. REP 0233), and the Observational/Interventions Research Ethics Committee of the London School of Hygiene \& Tropical Medicine (ref. 14872).

\section{Results}

Patient flow in study clinics was broadly organised around three key steps in the following order: 1) patient registration (file collection); 2) vital signs; and 3) HCW consultation. Individuals usually waited in different parts of the clinics for each step. The pathway taken depended on the reason for visit (many individuals also visited one or more of the in-clinic pharmacy, phlebotomist, and other specialist practitioners) and was implemented variably in clinics based on their size, design, and organisation of care. In most clinics, individuals attending for TB care (i.e., those being investigated for TB or taking anti-TB treatment) were 'fasttracked' and skipped steps 1 and 2 above. Clinics varied widely in size, population served, services offered, and organisation of care. Importantly, some clinics routinely asked patients to wait in covered outdoor waiting areas, whereas others had only indoor areas. All clinics in WC and no clinics in KZN operated a datetime appointment system for at least some patients (Supplementary table 5); no clinics had an active queue management system.

Twelve datasets were available for analysis from 11 clinics: six in KZN and five in WC (Table 1; clinic WC4 could not be visited for logistical reasons and clinic KZN1 was visited for a second time to attempt better coverage). Data were collected for 2,903 patients and visitors: 1,925 (66.3\%) in KZN and 978 (33.7\%) in WC). Across clinics, a median 70\% (interquartile range [IQR] 69\%-74\%) of clinic attendees were female. Most individual characteristics were similar between provinces, with the only large differences seen in 'main reason for clinic visit': in KZN clinics, a median $32.6 \%$ of clinic attendees reported attending for HIV care or antiretroviral therapy (ART), compared with a median 3.5\% in WC clinics. This was thought likely due, at least in part, to an error during data collection in WC clinics, with 'acute care' consistently incorrectly marked by those attending for HIV care (49\% in WC vs. $29 \%$ in KZN). Because no identifying details of individuals were 
medRxiv preprint doi: https://doi.org/10.1101/2021.07.21.21260806; this version posted July 23,2021 . The copyright holder for this preprint (which was not certified by peer review) is the author/funder, who has granted medRxiv a license to display the preprint in perpetuity.

It is made available under a CC-BY 4.0 International license .

collected, this could not be rectified, and the two categories were combined in analysis (but are shown separately in Table 1).

\section{Table 1. Characteristics of clinics, individuals attending, and staff working on the day of data collection, overall}

\section{Time spent in clinics}

Data were excluded from clinic KZN4 $(n=269)$ as all entrances and exits had not been monitored. Data from 2,634 individuals attending 10 clinics (11 data collection exercises) underwent multiple imputation and were included in this analysis (1,063 [40\%] missing time of arrival and 934 [35\%] missing time of departure; Supplementary table 4). Overall median time spent in clinic was 2 hours 36 minutes (IQR 01:36-3:43). This was similar in each province (KZN 02:33 [IQR 01:35-3:40; $n=1,656$ ]; WC 02:42 [IQR 01:37-03:49; $n=978$ ]).

Visit durations by demographics and reason for visit are provided in Supplementary table 6.

In univariable analysis (Table 2), there was strong evidence of an increase in mean time spent in clinic for individuals who were female ( $p<0.001)$, attending with a baby $(p<0.001)$, or attending with $\geq 1$ other person $(p<0.01)$. There was also strong evidence of differences by reason for visit $(p<0.01)$ : individuals attending for TB care and ante/post-natal care spent the shortest time in clinic. Mean time in clinic reduced by 15 minutes for each hour that arrival was delayed after $0700(p<0.001)$.

Table 2. Results of univariable and multivariable mixed-effects linear regression using imputed data, showing effects of different factors on total time spent in clinic ( $n=2,634 ; 11$ exercises in 10 clinics)

In multivariable analysis, longer mean times remained associated with being female $(13.5$ [95\% $\mathrm{Cl} 6-21]$ minutes longer than males) and attending with a baby $(18.8[95 \% \mathrm{Cl} 8-30]$ minutes longer than those attending without). Reason for visit $(p<0.01)$ and time of arrival $(p<0.001)$ also remained important: those attending for TB care or ante/post-natal care spent a mean 24.8 (95\% Cl 9-41) minutes and 32.6 (95\% Cl 1154) minutes less in clinic, respectively, than those attending for HIV/acute care, and mean time in clinic 
medRxiv preprint doi: https://doi.org/10.1101/2021.07.21.21260806; this version posted July 23,2021 . The copyright holder for this preprint (which was not certified by peer review) is the author/funder, who has granted medRxiv a license to display the preprint in perpetuity.

It is made available under a CC-BY 4.0 International license .

reduced by $14.9(95 \% \mathrm{Cl} 13-17)$ minutes for each hour that arrival was delayed after 0700 . The results of the fractional polynomial models showed that the linear model adequately described the relationship between the time at clinic and arrival time (Appendix 3.2.1).

\section{Proportion of time spent indoors vs. outdoors}

The 2,190 clinic attendees included in this analysis ( $\geq 5$ minutes captured; 10 visits; 9 clinics) spent a median 95.6\% (IQR 45.6-100) of their time indoors and a median 2.5\% (IQR 0-35.3) outdoors (Supplementary table 7), with the remainder in unknown locations. This varied by clinic (Figure 1A): in four clinics with an outdoor waiting area that was used as part of normal patient flow, individuals spent a median $13.7 \%$ (IQR 1.4-74.5; $\mathrm{n}$ $=1,362)$ of their time outdoors, compared with a median $0 \%($ IQR $0-1.4 ; n=828)$ outdoors among attendees at the five clinics without an outdoor waiting area or where the outdoor area was not used.

\section{Figure 1. Box and whiskers plots showing proportions of time spent indoors and outdoors, by clinic (panel A)}

\section{and for two visits to clinic KZN1, by selected reasons for visit (panel B)}

In clinics with outdoor waiting areas, the wide IQR (1.4-74.5) for estimated time spent outdoors reflects the considerable variation seen among attendees to clinic KZN1, where the outdoor waiting area is used only by individuals in the 'chronic' stream. For example, in the second exercise at KZN1, individuals attending for 'acute' care spent a median $89.8 \%$ (IQR 18.9-98.3; $\mathrm{n}=118$ ) of their time indoors, compared with those attending for HIV care, who spent a median 98.6\% (IQR 92.8-100; $n=125)$ of their time outdoors (Figure 1B). Estimates by reported reason for visit for each clinic are provided in Supplementary table 8.

\section{Occupancy density of indoor spaces}

Data from three clinics were sufficient to estimate occupancy density of at least three indoor spaces (Figure 2). In clinic KZN6 (Figure 2, panel 2), the occupancy density of area A consistently declined over the course of the day as individuals moved into areas B and C. Because of its relatively large volume, the occupancy density of area A never went above 0.9 persons $/ \mathrm{m}^{2}$. In contrast, in the smallest space (area C), occupancy 
medRxiv preprint doi: https://doi.org/10.1101/2021.07.21.21260806; this version posted July 23,2021 . The copyright holder for this preprint (which was not certified by peer review) is the author/funder, who has granted medRxiv a license to display the preprint in perpetuity.

It is made available under a CC-BY 4.0 International license .

peaked at around 1200, with density around or above 2.0 persons $/ \mathrm{m}^{2}$ from 1000-1200. In clinic KZN2 (panel

248 3), the smaller overall numbers of attendees meant that although the spaces are of similar size to clinic

249 KZN6, density was generally lower. Overall occupancy was highest in clinic WC1, but the larger waiting spaces in this clinic meant that occupancy density was never higher than 1.0 persons $/ \mathrm{m}^{2}$ (panel 4), even in the smallest space. Clinic WC1 also had a well-functioning date-time appointment system, which is likely why occupancy of these spaces was more evenly distributed over the day compared with the other two clinics.

Occupancy density by room volume (persons $/ \mathrm{m}^{3}$ ) was calculated for the same spaces (Supplementary table

9). This is a more relevant measure of occupancy density for predominantly airborne pathogens, such as

Mtb. All assessed waiting spaces in clinics KZN2 and KZN6 had relatively low ceilings (maximum height 2.5-

$2.7 \mathrm{~m}$ ) and occupancy density was higher (median 0.21-1.02 persons $/ \mathrm{m}^{3}$ ) than in spaces in clinic WC1, where ceilings were higher (maximum height 4.2-5.9 m; median occupancy density $0.10-0.14$ persons $/ \mathrm{m}^{3}$ ).

\section{Discussion}

262 We tracked 2,903 clinic attendees at $11 \mathrm{PHC}$ clinics in two provinces of South Africa. Median time spent in 263 clinic was 2 hours 36 minutes (IQR 01:36-03:43). People who arrived early in the morning spent longer in clinic, as did women and individuals attending with babies. Individuals attending for TB and maternal care spent less time in clinic. People attending clinics that had outdoor covered waiting areas spent more of their visit time outdoors, though differences were also seen between individuals attending the same clinic based on how care was organised for different 'streams'. In clinics with multiple indoor waiting areas, occupancy was often not distributed evenly between areas or over time; periods of high occupancy density (>2 persons $/ \mathrm{m}^{2}$ ) were observed in smaller waiting areas. 
medRxiv preprint doi: https://doi.org/10.1101/2021.07.21.21260806; this version posted July 23,2021 . The copyright holder for this preprint (which was not certified by peer review) is the author/funder, who has granted medRxiv a license to display the preprint in perpetuity.

It is made available under a CC-BY 4.0 International license .

270 Time spent in clinic was below the national target maximum time ${ }^{[29]}$ of three hours for around $60 \%$ of clinic 271 attendees (ranging from $48 \%$ to $82 \%$ across clinics), but was over four hours for around $20 \%$ (range $7 \%-37 \%$ )

272 and over five hours for around 9\% (range 4\%-27\%). Detailed comparison with other studies is challenging,

273 given the variation in operational characteristics of PHC clinics and methods used (Supplementary table 10).

274 On crude comparison, median time spent in clinic in our study was slightly higher than seen in recent South

275 African studies (Stime et al. [urban KZN, 2016], ${ }^{[24]}$ median 01:48 for sexually transmitted infection care and

276 median 02:46 for HIV care; Egbujie et al. [rural KZN, 2014], ${ }^{[42]}$ median 01:56 in nine PHCs) and slightly lower

277 than seen in older studies (Bachmann and Barron [urban WC, 1997], ${ }^{[23]}$ median 2.6 hours and 4.1 hours for

278 'preventive' and 'curative' care, respectively). Patterns in our data were also observed by previous

279 investigators, including longer times for individuals who arrived earlier ${ }^{[23,24,42]}$ and the early arrival of the

280 majority of attendees, often before the clinic opened. ${ }^{[30]} \mathrm{A}$ higher patient to nurse ratio was strongly

associated with longer waiting times in the study by Egbujie et al., ${ }^{[42]}$ but not in our study, possibly because

our estimates of staff numbers included all clinical staff, not only nurses. We are not aware of any previous studies that estimated proportions of time spent indoors vs. outdoors or the occupancy density of waiting areas.

Early arrival and queueing outside clinics is common in South Africa. It is influenced by the frequent absence of appointment and queue management systems; the organisation of services around the 'morning rush'; the lack of incentives for staff to change working patterns; and complex factors outside the health system, such as the availability of public transport and the community's trust in the system. Detailed exploration of these issues is beyond the scope of this paper, but some discussion can be found in the report of an Umoya omuhle workshop on patient flow that involved a range of South African experts. ${ }^{[43]}$ 
medRxiv preprint doi: https://doi.org/10.1101/2021.07.21.21260806; this version posted July 23,2021 . The copyright holder for this preprint (which was not certified by peer review) is the author/funder, who has granted medRxiv a license to display the preprint in perpetuity.

It is made available under a CC-BY 4.0 International license .

use of outdoor spaces may be less feasible in areas with lower temperatures. Thermal comfort and user acceptability are important considerations when planning changes to patient flow.

In clinics where it may be impractical to wait outdoors, risk indoors can be moderated through more even distribution of occupancy throughout the available space. For example, during the busiest period in a small clinic like KZN6 (106 people in the clinic [Figure 3]), restricting occupancy of the smaller waiting spaces (B and C) to 20 and 16 individuals, respectively, would have left 70 individuals in the largest space and resulted in an occupancy density of around 1 person $/ \mathrm{m}^{2}$ in all three spaces. This is in line with 2014 WHO guidelines for spatial separation as part of IPC for 'epidemic- and pandemic-prone acute respiratory infections', which recommend maintaining a distance of at least 1 metre between patients. ${ }^{[15]}$

South African draft national guidelines ${ }^{[44]}$ suggest a number of potential interventions to reduce waiting discussed briefly below.

\section{Potential interventions}

Interventions to improve flow can be classified broadly as targeting two domains: 1) reducing the number of

individuals overall and/or in particular spaces; and 2) reducing the time spent by attendees overall and/or in

particular spaces. Most measures affect both domains, sometimes indirectly.

Initiatives to reduce numbers of attendees include the Central Chronic Medicine Dispensing and Distribution (CCMDD) system, where certain groups of patients collect chronic medication from community-based 
medRxiv preprint doi: https://doi.org/10.1101/2021.07.21.21260806; this version posted July 23,2021 . The copyright holder for this preprint (which was not certified by peer review) is the author/funder, who has granted medRxiv a license to display the preprint in perpetuity.

It is made available under a CC-BY 4.0 International license .

317 'Lean', ${ }^{[50,51]}$ value-stream mapping, ${ }^{[52]}$ and other quality improvement methods, ${ }^{[53]}$ as well as more targeted changes in staffing or resources at specific points in clinical pathways. ${ }^{[24]}$

319 Streaming and triage interventions focus on the movement of people once they enter a health facility. In line with Ideal Clinic guidance, ${ }^{[28]}$ every clinic in our study operated a streaming system that allowed people attending for TB care to bypass many of the steps in the pathway. This is partly intended to reduce the risk of Mtb transmission and is made feasible by the relatively small numbers of people treated for TB at each clinic and because no additional triage process is required. Triage (broadly defined as the process of prioritising patients for care based on their needs $)^{[54]}$ has also been shown to reduce waiting times in a hospital in South Africa, though it was less effective when used in two PHC clinics. ${ }^{[55,56]}$ Effective triage can be challenging and resource-intensive to sustain, ${ }^{[57]}$ and sub-optimal implementation of symptom-based triage for TB IPC has been documented by several studies. ${ }^{[58-61]}$ Active queue management has also been tested: a qualitative study around the use of a 'Fast Queue' in clinics in KZN found that the use of multiple, managed queues was generally well-received by attendees, particularly if accompanied by smooth (i.e., unidirectional) flow and effective communication with HCWs, though there were still those who experienced long waiting times. ${ }^{[62]}$

Date-time appointment systems have been most widely used to reduce both numbers of people and time spent in clinics. Appointment systems have been shown to reduce waiting times in outpatient ART clinics in Ethiopia ${ }^{[63]}$ and Kenya, ${ }^{[64]}$ antenatal clinics in Mozambique, ${ }^{[65]}$ and PHC clinics in South Africa, ${ }^{[42]}$ the last as part of a suite of interventions that included streaming, training, and infrastructure upgrades. Investigators describe generally encouraging results, though they also highlight the considerable challenges involved in standardising implementation at facilities that are differently organised. During the Umoya omuhle patient flow workshop, discussions around appointment system implementation emphasised the importance of support processes (such as pre-retrieval of files) and technological infrastructure in sustaining this complex intervention. ${ }^{[43]}$ 
medRxiv preprint doi: https://doi.org/10.1101/2021.07.21.21260806; this version posted July 23,2021 . The copyright holder for this preprint (which was not certified by peer review) is the author/funder, who has granted medRxiv a license to display the preprint in perpetuity.

It is made available under a CC-BY 4.0 International license .

\section{Recommendations}

Building flexibility into the organisation of flow would allow a clinic to adapt to and absorb periods of increased traffic without putting patients or staff at risk; for example, by moving people from an overcrowded area to one that is relatively empty, or by activating 'overflow' covered outdoor waiting areas. However, any such initiative would require 1) a queue management system, to ensure that individuals moved between areas are not placed at a disadvantage, and 2) clinic managers to have a) easy access to real-time information about flow and b) the resources and freedom to try to improve flow. ${ }^{[27]}$ Patient flow can be difficult to measure quickly: previous published descriptions focus on largely qualitative descriptions of observed movement patterns. ${ }^{[23,66]}$ Occupancy density, however, is easy to measure (e.g., through manual headcounts) and, measured periodically across a clinic, could be used as a proxy estimate for flow. We suggest that regular, light-touch ('diagnostic') approximation of this metric may have numerous potential direct and indirect benefits, including improved efficiency; shorter waiting times; better clinic-specific decision-making; and a strengthened relationship between the clinic and its community. ${ }^{[27,43,67]}$

Importantly, interventions intended to reduce attendance and waiting times may adversely affect the flow around the which the clinic was designed and may therefore increase the rate of transmission to an individual during the time they do spend in the clinic. Most clinics are designed with waiting areas that get successively smaller as patients move through the pathway; as pathways diverge, patients 'diffuse' through the clinic and one would expect occupancy to be lower. However, if the overall 'patient load' is greater than the capacity of the clinic, or if different stages of the pathway are variably efficient, or if certain attendees (e.g., those with appointments) are allowed to skip parts of the queue, bottlenecks can arise in areas that are designed to hold fewer people, leading to higher than optimal occupancy of 'downstream' areas and/or under-use of 'upstream' areas. Interventions to improve flow and reduce waiting times are acutely vulnerable to achieving "many small successes and one big failure" ${ }^{[68]}$ and should be undertaken with careful consideration of potential effects on other parts of the pathway, possible increases in risk of disease 
medRxiv preprint doi: https://doi.org/10.1101/2021.07.21.21260806; this version posted July 23,2021 . The copyright holder for this preprint (which was not certified by peer review) is the author/funder, who has granted medRxiv a license to display the preprint in perpetuity.

It is made available under a CC-BY 4.0 International license .

transmission, and adjustments that may be needed in resource allocation, ventilation, and the organisation of care.

\section{Limitations}

367 The method employed in this study was relatively inexpensive, built on methods already widely used in 368 South African PHCs, and included elements that could be incorporated into routine estimation of waiting times and flow. Numbers of individuals who declined to participate were not recorded and we were therefore unable to assess for selection bias introduced by the enrolment process. Starting data collection after some individuals had arrived and stopping data collection at 1400 (because of logistical restrictions) reduced the numbers of individuals whose data could be used to estimate total waiting time, requiring the use of multiple imputation to deal with missing data. Multiple imputation assumes that the data are missing at random, which means that the observed values can be used to predict the missing values. However, if the assumption is incorrect, the results may be biased. Furthermore, the validity of results derived from multiply imputed data depend on the appropriateness of the imputation model. Future exercises should, at a minimum, continue to record clinic exits for as long as possible. Because of variability between and within clinics, and because data were collected on only one day from almost all clinics, estimates presented here should not be considered representative of the two provinces, types of clinics, or the clinics themselves. In busy clinics in particular, many attendees' barcodes were not scanned every time at every scanning point, and estimates of waiting area occupancy and time spent indoors or outdoors should be treated as approximations. Even so, our headline findings are plausible and consistent with those from other studies.

\section{Conclusions}

384 Measuring patient flow is important for estimating clinic efficiency and disease transmission risk. In our study, women, individuals arriving early, and those attending with young children spent longer at clinic. Attendees generally waited where they were asked to: using outdoor waiting areas as part of patient pathways increased the proportion of visit time spent outdoors. Occupancy of indoor spaces varied considerably over the day and people often were not distributed evenly throughout the available space. 
medRxiv preprint doi: https://doi.org/10.1101/2021.07.21.21260806; this version posted July 23,2021 . The copyright holder for this preprint (which was not certified by peer review) is the author/funder, who has granted medRxiv a license to display the preprint in perpetuity.

It is made available under a CC-BY 4.0 International license .

391 List of abbreviations WC: Western Cape

\section{Declarations}

\section{Consent for publication}

Not applicable. material.

Regular, light-touch estimation of occupancy density (as a proxy for patient flow) may help staff to assess for the risk of nosocomial transmission and guide the use of interventions to reduce time spent in risky spaces.

ART: antiretroviral therapy; $\mathrm{Cl}$ : confidence interval; HCW: health care worker; hh: hours; IPC: infection prevention and control; IQR: interquartile range; KZN: Kwa-Zulu Natal; mm: minutes; Mtb: Mycobacterium tuberculosis; NCD: noncommunicable disease; PHC: primary health care; REDCap: Research Electronic Data Capture; ref.: reference; SARS-COV-2: severe acute respiratory syndrome coronavirus 2; TB: tuberculosis;

\section{Ethics approval and consent to participate}

Identifiable data were not collected from participating individuals and written informed consent was

therefore not requested. This study received ethical approval from the Biomedical Research Ethics

Committee of the University of KwaZulu-Natal (ref. BE082/18), the Human Research Ethics Committee of the Faculty of Health Sciences of the University of Cape Town (ref. 165/2018), the Research Ethics Committee of Queen Margaret University (ref. REP 0233), and the Observational/Interventions Research Ethics Committee of the London School of Hygiene \& Tropical Medicine (ref. 14872).

\section{Availability of data and materials}

Data will be available from LSHTM DataCompass. Questionnaires used are provided in the supplementary 
medRxiv preprint doi: https://doi.org/10.1101/2021.07.21.21260806; this version posted July 23,2021 . The copyright holder for this preprint (which was not certified by peer review) is the author/funder, who has granted medRxiv a license to display the preprint in perpetuity.

It is made available under a CC-BY 4.0 International license .

\section{Competing interests}

411 The authors declare that they have no competing interests. All authors have completed the ICMJE uniform

412 disclosure form at www.icmje.org and declare: financial support from the Economic and Social Research

413 Council (UK) and from The Bloomsbury SET (Research England) for the submitted work; no financial

414 relationships with any organizations that might have an interest in the submitted work in the previous three

415 years; and no other relationships or activities that could appear to have influenced the submitted work.

\section{$416 \quad$ Funding}

417 The support of the Economic and Social Research Council (UK) is gratefully acknowledged. The Umoya

418 omuhle study is funded by the Antimicrobial Resistance Cross Council Initiative supported by the seven

419 research councils in partnership with other funders including support from the GCRF (ref. ES/P008011/1).

420 Additional support was received from The Bloomsbury SET (Research England; ref. CCF17-7779). TAY is

421 funded via an NIHR Academic Clinical Fellowship and acknowledges support from the NIHR Imperial

422 Biomedical Research Centre.

\section{Authors' contributions}

$\begin{array}{ll}\text { Conceptualisation } & \text { ADG, ASK, AV, HM, KK, NM, TAY } \\ \text { Methodology } & \text { ADG, ASK, AV, NM } \\ \text { Formal analysis } & \text { ASK, KB, NM } \\ \text { Investigation } & \text { ADG, ASK, IIK, IG } \\ \text { Resources } & \text { ADG, ASK, IG, NM } \\ \text { Data curation } & \text { ASK } \\ \text { Writing - original draft } & \text { ASK } \\ \text { Writing - review \& editing } & \text { All authors } \\ \text { Visualisation } & \text { ASK } \\ \text { Supervision } & \text { ADG, AV, KB } \\ \text { Project administration } & \text { ADG, ASK, IG } \\ \text { Funding acquisition } & \text { ADG, KK }\end{array}$


medRxiv preprint doi: https://doi.org/10.1101/2021.07.21.21260806; this version posted July 23,2021 . The copyright holder for this preprint (which was not certified by peer review) is the author/funder, who has granted medRxiv a license to display the preprint in perpetuity.

It is made available under a CC-BY 4.0 International license .

1

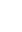

6

\section{Acknowledgments}

Our thanks to the managers, staff, and attendees at all study clinics for their participation, enthusiasm, and patience; to Dr Bart Willems for guidance around methods; to Dr Gavin Reagon for additional advice, particularly around appointment systems; and to all participants of the Umoya omuhle participatory workshop on waiting times and patient flow, ${ }^{[43]}$ held in South Africa in August 2019.

Special thanks to teams in Somkhele and Cape Town who were involved in data collection: Dr Amy Burdzik, Anathi Mngxekeza, Awethu Gawulekapa, Duduzile Mkhwanazi, Emmerencia Gumede, Godfrey Manuel, Nompilo Ndlela, Nonhlanhla Madlopha, Nozipho Mthethwa, Phumzile Nywagi, Precious Mathenjwa, Samantha Moyo, Seonaid Kabiah, Sinead Murphy, Siphokazi Adonisi, Siphosethu Titise, Sithembiso Luthuli, Sphiwe Mthethwa, Suzanne Key, Tamia Jansen, Thandekile Nene, Yolanda Qeja, Yutu Dlamini, and Zinhle Mkhwanazi.

Umoya omuhle was a multidisciplinary initiative involving several institutions and a team of over 100 people (Supplementary table 11).

\section{References}

McCreesh N, Grant AD, Yates TA, Karat AS, White RG. Tuberculosis from transmission in clinics in high HIV settings may be far higher than contact data suggest. Int J Tuberc Lung Dis. 2020;24(4):403-8.

Gandhi NR, Weissman D, Moodley P, et al. Nosocomial Transmission of Extensively Drug-Resistant Tuberculosis in a Rural Hospital in South Africa. J Infect Dis. 2013;207(1):9-17.

Lessells R, Moosa Y, de Oliveira T. Report into a nosocomial outbreak of coronavirus disease 2019 (COVID-19) at Netcare St. Augustine's Hospital. 2020.

https://www.krisp.org.za/manuscripts/StAugustinesHospitalOutbreakInvestigation_FinalReport_15may2020_c omp.pdf (accessed 2021 Jan 26)

Basu S, Stuckler D, McKee M. Addressing Institutional Amplifiers in the Dynamics and Control of Tuberculosis Epidemics. Am J Trop Med Hyg. 2011;84(1):30-7.

Baussano I, Nunn P, Williams B, Pivetta E, Bugiani M, Scano F. Tuberculosis among health care workers. Emerg Infect Dis. 2011;17(3):488-94.

Grobler L, Mehtar S, Dheda K, et al. The epidemiology of tuberculosis in health care workers in South Africa: a systematic review. BMC Health Serv Res. 2016;16(1):416.

Abbas M, Robalo Nunes T, Martischang R, et al. Nosocomial transmission and outbreaks of coronavirus disease 2019: the need to protect both patients and healthcare workers. Antimicrob Resist Infect Control. 2021;10(1):7. 
medRxiv preprint doi: https://doi.org/10.1101/2021.07.21.21260806; this version posted July 23, 2021. The copyright holder for this preprint (which was not certified by peer review) is the author/funder, who has granted medRxiv a license to display the preprint in perpetuity.

It is made available under a CC-BY 4.0 International license .

Yates TA, Khan PY, Knight GM, et al. The transmission of Mycobacterium tuberculosis in high burden settings. Lancet Infect Dis. 2016;16(2):227-38.

Delikhoon M, Guzman MI, Nabizadeh R, Norouzian Baghani A. Modes of Transmission of Severe Acute Respiratory Syndrome-Coronavirus-2 (SARS-CoV-2) and Factors Influencing on the Airborne Transmission: A Review. Int J Environ Res Public Health. 2021;18(2).

11 Kwon K-S, Park J-I, Park YJ, Jung D-M, Ryu K-W, Lee J-H. Evidence of Long-Distance Droplet Transmission of SARS-CoV-2 by Direct Air Flow in a Restaurant in Korea. J Korean Med Sci. 2020;35(46).

Yates TA, Tanser F, Abubakar I. Plan Beta for tuberculosis: it's time to think seriously about poorly ventilated congregate settings. Int J Tuberc Lung Dis. 2016;20(1):5-10.

14 World Health Organization. WHO policy on TB infection control in health-care facilities, congregate settings, and households. 2009. http://www.ncbi.nlm.nih.gov/books/NBK179249/ (accessed 2019 Dec 1)

World Health Organization. Infection prevention and control of epidemic- and pandemic-prone acute respiratory infections in health care: WHO guidelines. 2014. http://apps.who.int/iris/bitstream/10665/112656/1/9789241507134_eng.pdf?ua=1 (accessed 2020 Jul 30)

16 Luque-Fernandez MA, Van Cutsem G, Goemaere E, et al. Effectiveness of patient adherence groups as a model of care for stable patients on antiretroviral therapy in Khayelitsha, Cape Town, South Africa. PloS One. 2013;8(2):e56088.

17 South Africa National Department of Health. Get Checked Go Collect: CCMDD. https://getcheckedgocollect.org.za/ccmdd/ (accessed $2021 \mathrm{Feb} 8$ )

Fox GJ, Redwood L, Chang V, Ho J. The effectiveness of individual and environmental infection control measures in reducing the transmission of Mycobacterium tuberculosis: a systematic review. Clin Infect Dis. 2020;72(1):1526.

Karat AS, Gregg M, Barton HE, et al. Evidence for the use of triage, respiratory isolation, and effective treatment to reduce the transmission of Mycobacterium tuberculosis in health care settings: a systematic review. Clin Infect Dis. 2020;72(1):155-72.

Cox H, Escombe R, McDermid C, et al. Wind-Driven Roof Turbines: A Novel Way to Improve Ventilation for TB Infection Control in Health Facilities. PLOS ONE. 2012;7(1).

Hunter JR, Asmall S, Ntshengedzeni MR, Chandran TM, Tucker J-M, Mokgalagadi Y. The Ideal Clinic in South Africa: progress and challenges in implementation. South African Health Review 2017. 2017. https://www.hst.org.za/publications/South\%20African\%20Health\%20Reviews/11_The\%20ldeal\%20Clinic\%20in \%20South\%20Africa_progress\%20and\%20challenges\%20in\%20implementation.pdf (accessed 2020 Jul 30) Health Systems Trust. South African District Health Barometer, 2019/20. 2020. https://www.hst.org.za/publications/District\%20Health\%20Barometers/DHB\%20201920\%20Complete\%20Book.pdf (accessed 2021 Jan 26)

Bachmann MO, Barron P. Why wait so long for child care? An analysis of waits, queues and work in a South African urban health centre. Trop Doct. 1997;27(1):34-8.

Stime KJ, Garrett N, Sookrajh Y, et al. Clinic flow for STI, HIV, and TB patients in an urban infectious disease clinic offering point-of-care testing services in Durban, South Africa. BMC Health Serv Res. 2018;18(1):363.

Naidoo K, van Wyk J. What the elderly experience and expect from primary care services in KwaZulu-Natal, South Africa. Afr J Prim Health Care Fam Med. 2019;11(1).

Voce A, Zwama G, MacGregor H, Grant AD, Kielmann K. Compromised TB infection prevention and control in south African primary care facilities: a whole systems perspective. 50th World Conf Lung Health Int Union Tuberc Lung Dis. 2019;Abstract PS-37-911-02.

Daniels J, Zweigenthal V, Reagon $G$. Assessing the impact of a waiting time survey on reducing waiting times in urban primary care clinicss in Cape Town, South Africa. J Public Health Afr. 2017;8:23-9. 
medRxiv preprint doi: https://doi.org/10.1101/2021.07.21.21260806; this version posted July 23,2021 . The copyright holder for this preprint (which was not certified by peer review) is the author/funder, who has granted medRxiv a license to display the preprint in perpetuity.

It is made available under a CC-BY 4.0 International license .

South Africa National Department of Health. Ideal Clinic Integrated Clinical Services Management Manual. https://www.idealhealthfacility.org.za/docs/Integrated\%20Clinical\%20Services\%20Management\%20\%20Manu al\%205th\%20June\%20FINAL.pdf (accessed 2010 Jul 2)

29 South Africa National Department of Health. National policy on management of patient waiting time in out patient departments. 2015.

https://www.idealhealthfacility.org.za/docs/policies/Patient\%20Waiting\%20time\%20Policy\%2014\%20Novembe r\%202016\%20PDF.pdf (accessed 2020 Jul 30)

Reagon G, Igumbor E. Strengthening Health Systems through training of Health Care Providers in the conduct of Routine Waiting Time and System Efficiency Surveys. Stud Health Technol Inform. 2010;590-4.

Kielmann K, Karat AS, Zwama G, et al. Tuberculosis infection prevention and control: why we need a whole systems approach. BMC Infect Dis Poverty. 2020;9(1):56.

Kamel Boulos MN, Berry G. Real-time locating systems (RTLS) in healthcare: a condensed primer. Int J Health Geogr. 2012;11(1):25.

Ryan D, Denman S, Fookes C, Sridharan S. Crowd Counting Using Group Tracking and Local Features. In: 2010 7th IEEE International Conference on Advanced Video and Signal Based Surveillance. 2010. p. 218-24.

Rahmalan H, Nixon MS, Carter JN. On crowd density estimation for surveillance. In: IET Conference on Crime and Security. 2006. p. 540-5.

Rodriguez M, Laptev I, Sivic J, Audibert J-Y. Density-aware person detection and tracking in crowds. In: 2011 International Conference on Computer Vision. 2011. p. 2423-30.

Perez-Diaz-de-Cerio D, Hernández-Solana Á, Valdovinos A, Valenzuela J. A Low-Cost Tracking System for Running Race Applications Based on Bluetooth Low Energy Technology. Sensors. 2018;18(3):922.

37 Fosso Wamba S. Guest Editorial for the Special Issue on RFID-enabled Healthcare: Applications, Issues and Benefits. J Med Syst. 2012;36(6):3389-92.

38 Singman EL, Haberman CV, Appelbaum J, et al. Electronic Tracking of Patients in an Outpatient Ophthalmology Clinic to Improve Efficient Flow: A Feasibility Analysis and Benchmarking Study. Qual Manag Health Care. 2015;24(4):190-9.

39 Harris PA, Taylor R, Thielke R, Payne J, Gonzalez N, Conde JG. Research electronic data capture (REDCap) -A metadata-driven methodology and workflow process for providing translational research informatics support. J Biomed Inform. 2009;42(2):377-81.

Harris PA, Taylor R, Minor BL, et al. The REDCap consortium: Building an international community of software platform partners. J Biomed Inform. 2019;95:103208.

41 The Inkscape Project. Inkscape. https://inkscape.org/ (accessed 2021 Jun 1)

42 Egbujie BA, Grimwood A, Mothibi-Wabafor EC, et al. Impact of 'Ideal Clinic' implementation on patient waiting time in primary healthcare clinics in KwaZulu-Natal Province, South Africa: A before-and-after evaluation. S Afr Med J. 2018;108(4):311.

43 Umoya omuhle. Workshop report: measuring and modifying patient flow and waiting times in South African primary health care clinics. 2020. https://www.lshtm.ac.uk/sites/default/files/202011/Summary\%20report\%20on\%20patient\%20flow\%20\%26\%20waiting\%20times.pdf (accessed 2021 Jan 26)

44 South Africa National Department of Health. Draft National Guideline for Management of Patient Waiting Times at Health Facilities. 2019. https://www.idealhealthfacility.org.za/App/Document/Download/60 (accessed 2020 Jul 2)

45 Dorward J, Msimango L, Gibbs A, et al. Understanding how community antiretroviral delivery influences engagement in HIV care: a qualitative assessment of the Centralised Chronic Medication Dispensing and Distribution programme in South Africa. BMJ Open. 2020;10(5):e035412.

46 Tukei BB, Fatti G, Tiam A, et al. Twelve-Month Outcomes of Community-Based Differentiated Models of Multimonth Dispensing of ART Among Stable HIV-Infected Adults in Lesotho: A Cluster-Randomized Noninferiority Trial. J Acquir Immune Defic Syndr 1999. 2020;85(3):280-91. 
medRxiv preprint doi: https://doi.org/10.1101/2021.07.21.21260806; this version posted July 23, 2021. The copyright holder for this preprint (which was not certified by peer review) is the author/funder, who has granted medRxiv a license to display the preprint in perpetuity.

It is made available under a CC-BY 4.0 International license .

Fatti G, Ngorima-Mabhena N, Mothibi E, et al. Outcomes of Three- Versus Six-Monthly Dispensing of Antiretroviral Treatment (ART) for Stable HIV Patients in Community ART Refill Groups: A Cluster-Randomized Trial in Zimbabwe. J Acquir Immune Defic Syndr 1999. 2020;84(2):162-72.

48 Prust ML, Banda CK, Nyirenda R, et al. Multi-month prescriptions, fast-track refills, and community ART groups: results from a process evaluation in Malawi on using differentiated models of care to achieve national HIV treatment goals. J Int AIDS Soc. 2017;20(Suppl 4):21650.

49 Cassidy T, Grimsrud A, Keene C, et al. Twenty-four-month outcomes from a cluster-randomized controlled trial of extending antiretroviral therapy refills in ART adherence clubs. J Int AIDS Soc. 2020;23(12):e25649.

50 Naidoo L, Mahomed OH. Impact of Lean on patient cycle and waiting times at a rural district hospital in KwaZulu-Natal. Afr J Prim Health Care Fam Med. 2016;8(1).

51 Monroe-Wise A, Reisner E, Sherr K, et al. Using lean manufacturing principles to evaluate wait times for HIVpositive patients in an urban clinic in Kenya. Int J STD AIDS. 2017;28(14):1410-8.

Hoffmann CJ, Milovanovic M, Kinghorn A, et al. Value stream mapping to characterize value and waste associated with accessing HIV care in South Africa. PloS One. 2018;13(7):e0201032.

The Health Foundation. Improving patient flow across organisations and pathways. 2013. https://www.health.org.uk/publications/improving-patient-flow-across-organisations-and-pathways (accessed 2021 Feb 9)

54 Gottschalk SB. The cape triage score: a new triage system South Africa. Proposal from the cape triage group. Emerg Med J. 2006;23(2):149-53.

Bruijns SR, Wallis LA, Burch VC. Effect of introduction of nurse triage on waiting times in a South African emergency department. Emerg Med J. 2008;25(7):395-7.

Swart A-T, Muller CE, Rabie T. The role of triage to reduce waiting times in primary health care facilities in the North West province of South Africa. Health SA Gesondheid. 2018;23.

57 Stott BA, Moosa S. Exploring the sorting of patients in community health centres across Gauteng Province, South Africa. BMC Fam Pract. 2019;20(1):5.

Naidoo S, Seevnarain K, Nordstrom DL. Tuberculosis infection control in primary health clinics in eThekwini, KwaZulu-Natal, South Africa. Int J Tuberc Lung Dis. 2012;16(12):1600-4.

Reid MJ, Saito S, Nash D, Scardigli A, Casalini C, Howard AA. Implementation of tuberculosis infection control measures at HIV care and treatment sites in sub-Saharan Africa. Int J Tuberc Lung Dis. 2012;16(12):1605-12.

Claassens MM, van Schalkwyk C, du Toit E, et al. Tuberculosis in healthcare workers and infection control measures at primary healthcare facilities in South Africa. PloS One. 2013;8(10):e76272.

Engelbrecht MC, Kigozi G, Janse van Rensburg AP, Van Rensburg DHCJ. Tuberculosis infection control practices in a high-burden metro in South Africa: A perpetual bane for efficient primary health care service delivery. Afr J Prim Health Care Fam Med. 2018;10(1):e1-6.

Sokhela DG, Makhanya NJ, Sibiya NM, Nokes KM. Experiences of Fast Queue health care users in primary health care facilities in eThekwini district, South Africa. Curationis. 2013;36(1):8 pages.

Atnafu A, Haile Mariam D, Wong R, Awoke T, Wondimeneh Y. Improving Adult ART Clinic Patient Waiting Time by Implementing an Appointment System at Gondar University Teaching Hospital, Northwest Ethiopia. Adv Public Health. 2015;2015:1-5.

64 Kwena ZA, Njoroge BW, Cohen CR, et al. The feasibility, time savings and economic impact of a designated time appointment system at a busy HIV care clinic in Kenya: a randomized controlled trial. J Int AIDS Soc. 2015;18:19876.

Steenland M, Dula J, de Albuquerque A, et al. Effects of appointment scheduling on waiting time and utilisation of antenatal care in Mozambique. BMJ Glob Health. :9.

66 Dixon CA, Punguyire D, Mahabee-Gittens M, Ho M, Lindsell CJ. Patient Flow Analysis in Resource-Limited Settings: A Practical Tutorial and Case Study. Glob Health Sci Pract. 2015;3(1):126-34. 
medRxiv preprint doi: https://doi.org/10.1101/2021.07.21.21260806; this version posted July 23,2021 . The copyright holder for this preprint (which was not certified by peer review) is the author/funder, who has granted medRxiv a license to display the preprint in perpetuity.

It is made available under a CC-BY 4.0 International license.

598

59968

600

8

601

602
Public Health Response to HIV. Curr HIV/AIDS Rep. 2019;16(4):279-91.

Kreindler SA. The three paradoxes of patient flow: an explanatory case study. BMC Health Serv Res. 2017;17(1):481. 
medRxiv preprint doi: https://doi.org/10.1101/2021.07.21.21260806; this version posted July 23,2021 . The copyright holder for this preprint (which was not certified by peer review) is the author/funder, who has granted medRxiv a license to display the preprint in perpetuity.

It is made available under a CC-BY 4.0 International license .

\section{Tables and figures}

Table 1. Characteristics of clinics, individuals attending, and staff working on the day of data collection, overall and by province ( $N=12$ exercises at 11 clinics; $N=2,903$ attendees)

\begin{tabular}{|c|c|c|c|}
\hline Characteristic & All clinics, $n$ & KZN province, $\mathrm{n}$ (row \%) & WC province, n (row \%) \\
\hline Number of clinics & 11 & $6(54.5)$ & $5(45.5)$ \\
\hline Number of data collection exercises & $12 \|$ & $7(58.3)$ & $5(41.7)$ \\
\hline Hours of data collection, $\mathrm{HH}: M M$ & 77:02 & $44: 32(57.8)$ & $32: 30(42.2)$ \\
\hline Patients \& visitors included & 2,903 & $1,925(66.3)$ & $978(33.7)$ \\
\hline On the day of data collection & $\begin{array}{l}\text { Median (range) per } \\
\text { exercise }\end{array}$ & $\begin{array}{l}\text { Median (range) per } \\
\text { exercise }\end{array}$ & $\begin{array}{l}\text { Median (range) per } \\
\text { exercise }\end{array}$ \\
\hline Hours of data collection, $\mathrm{HH}: M M$ & 06:15 (05:37-07:18) & 06:15 (05:40-07:08) & $06: 15(05: 37-07: 18)$ \\
\hline Clinical staff working*, $n$ & $16(3-45)$ & $14(8-45)$ & $17(3-45)$ \\
\hline Administrative staff working*, $n$ & $11(4-21)$ & $10(7-17)$ & $16(4-21)$ \\
\hline Patients ${ }^{\dagger}$ per clinical staff*, $\mathrm{n}$ & $14(5-27)$ & $14(6-27)$ & $14(5-18)$ \\
\hline Patients and visitors included, $\mathrm{n}$ & $252(69-417)$ & $269(170-417)$ & $144(69-337)$ \\
\hline Proportion female, \% & $70.0(56.3-789.7)$ & $71.2(68.4-74.8)$ & $69.2(56.3-79.7)$ \\
\hline \multicolumn{4}{|l|}{ Proportion aged } \\
\hline $0-5$ years, $\%$ & $9.1(0.7-30.8)$ & $8.4(7.1-10.1)$ & $10.4(5.6-30.8)$ \\
\hline $6-15$ years, $\%$ & $3.4(0-9.4)$ & $3.5(1.5-6.2)$ & $3.2(0-8.3)$ \\
\hline $16-25$ years, $\%$ & $17.3(6.3-25.7)$ & $20.1(15.9-25.3)$ & $15.0(13.1-17.4)$ \\
\hline $26-35$ years, $\%$ & $27.3(19.4-36.2)$ & $27.8(25.8-32.0)$ & $22.5(19.4-36.2)$ \\
\hline $36-45$ years, $\%$ & $18.6(15.0-35.7)$ & $18.0(15.3-24.8)$ & $20.3(15.0-21.1)$ \\
\hline$>45$ years, $\%$ & $18.0(7.2-35.4)$ & $18.4(17.1-22.1)$ & $16.9(7.2-35.4)$ \\
\hline $\begin{array}{l}\text { Proportion attending with a baby or } \\
\text { very young child, } \%\end{array}$ & $11.5(0.7-36.2)$ & $11.2(0.7-17.9)$ & $12.1(10.4-36.2)$ \\
\hline $\begin{array}{l}\text { Proportion attending with } \geq 1 \text { other } \\
\text { person } \neq, \%\end{array}$ & $24.9(1.5-60.8)$ & $22.9(1.5-35.9)$ & $27.9(15.4-60.8)$ \\
\hline \multicolumn{4}{|l|}{ Proportion attending for } \\
\hline Acute care/minor problems, $\%$ & $37.0(9.3-53.5)$ & $28.8(9.3-41.7)$ & $48.7(34.8-53.5)$ \\
\hline HIV care/ART, \% & $16.1(0.8-85.9)$ & $32.6(14.2-85.9)$ & $3.5(0.8-7.1) 9$ \\
\hline Tuberculosis, \% & $3.8(0.6-16.3)$ & $2.2(0.6-16.3)$ & $9.0(2.1-13.3)$ \\
\hline NCDs (including mental health), \% & $4.4(0-16.9)$ & $4.1(0.4-5.3)$ & $6.9(0-16.9)$ \\
\hline Mother \& child§, \% & $12.4(0.7-30.4)$ & $14.7(0.7-19.7)$ & $7.7(4.2-30.4)$ \\
\hline Maternal \& obstetric, \% & $2.9(0-8.7)$ & $3.2(0-4.7)$ & $2.7(0-8.7)$ \\
\hline Accompanying a patient, $\%$ & $14.6(1.5-22.5)$ & $12.4(1.5-17.1)$ & $19.2(10.1-22.5)$ \\
\hline Attending for another person, $\%$ & $2.6(0-6.3)$ & $2.9(0-4.3)$ & $1.7(0-6.3)$ \\
\hline
\end{tabular}

*Based on questionnaire administered to manager or senior member of staff; data from clinic KZ04 (including number of staff) captured only for HIV/chronic unit

+Counted as those who reported a main visit reason that was not 'accompanying' or 'attending for another person'

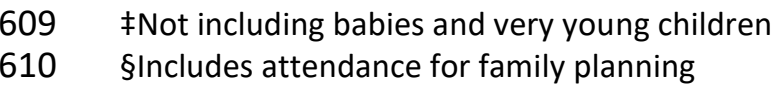

$\|$ Two exercises conducted at clinic KZ01, roughly one month apart subsequent analysis. 
medRxiv preprint doi: https://doi.org/10.1101/2021.07.21.21260806; this version posted July 23,2021 . The copyright holder for this preprint (which was not certified by peer review) is the author/funder, who has granted medRxiv a license to display the preprint in perpetuity.

It is made available under a CC-BY 4.0 International license .

615 Table 2. Results of univariable and multivariable mixed-effects linear regression using imputed data, 616 showing effects of different factors on total time spent in clinic $(n=2,634 ; 11$ exercises in 10 clinics)

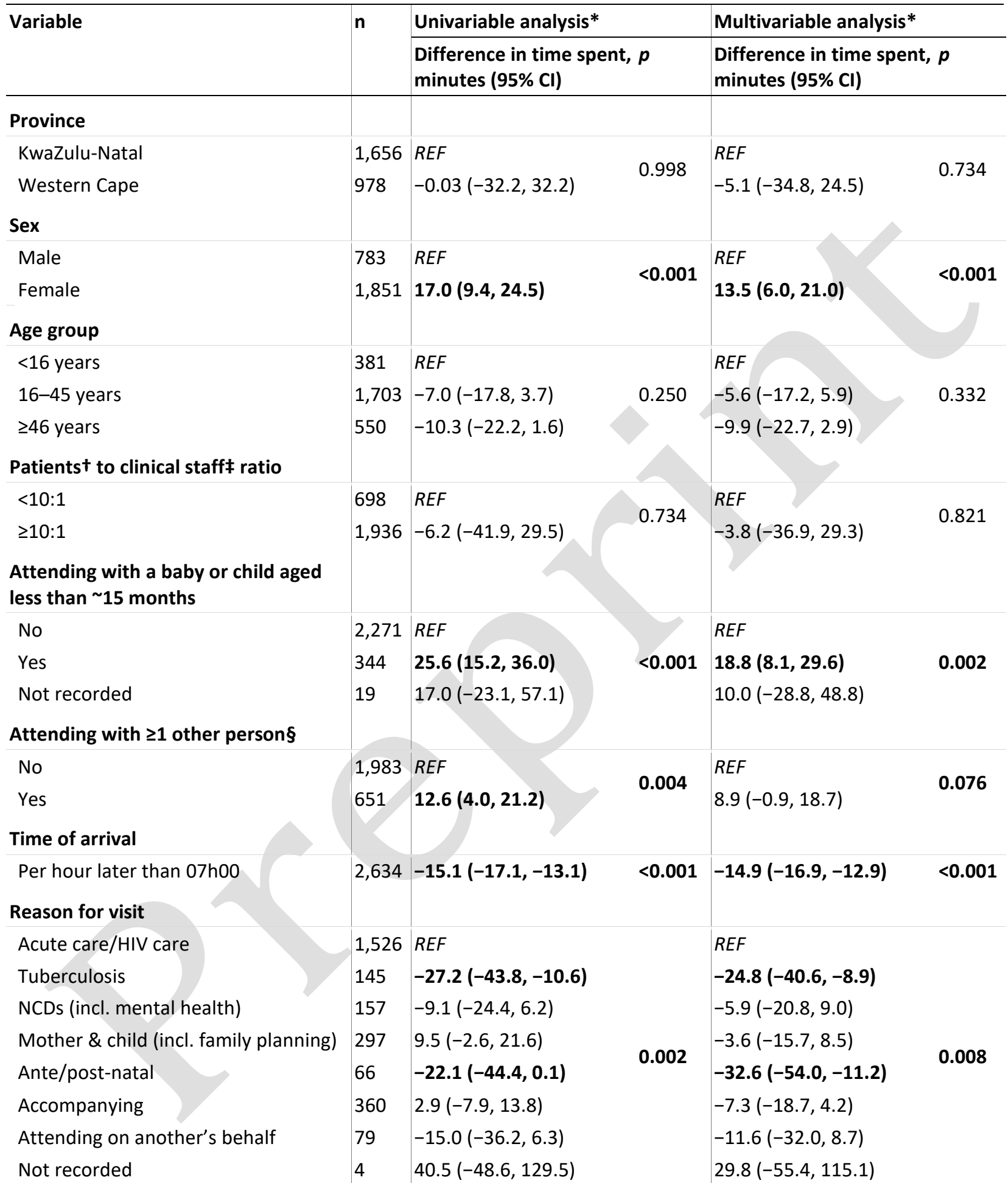

*Mixed-effects linear regression with a random effect for clinic day (i.e., two visits to clinic 1 treated as separate 618 clusters).

†Attendees who reported a main visit reason that was not 'accompanying' or 'attending for another person' FIncludes enrolled ('staff') and professional nurses, clinical nurse practitioners, clinical and enrolled nursing assistants, and doctors. Does not include lay-counsellors, peer navigators, community health workers, pharmacists, or nursing/medical students.

623 \$Not including babies and very young children

624 ART: antiretroviral therapy; $\mathrm{Cl}$ : confidence interval; incl.: including; REF: reference; NCD: non-communicable diseases 
medRxiv preprint doi: https://doi.org/10.1101/2021.07.21.21260806; this version posted July 23, 2021. The copyright holder for this preprint (which was not certified by peer review) is the author/funder, who has granted medRxiv a license to display the preprint in perpetuity.

It is made available under a CC-BY 4.0 International license .

Figure 1. Box and whiskers plots showing proportions of time spent indoors and outdoors, by clinic (panel A) and for two visits to clinic KZN1, by selected reasons for visit (panel B)

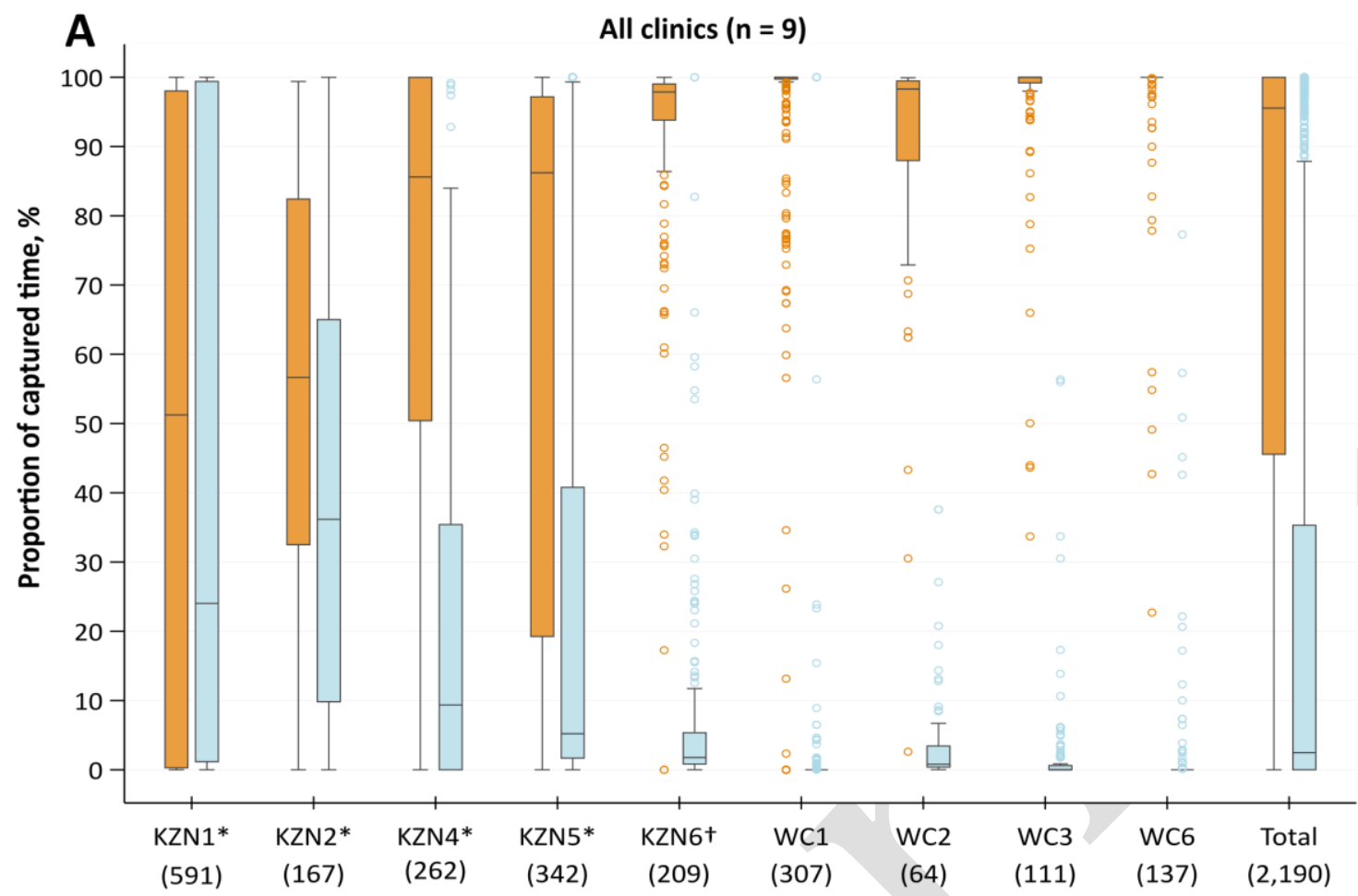

Clinic code

(n attendees)
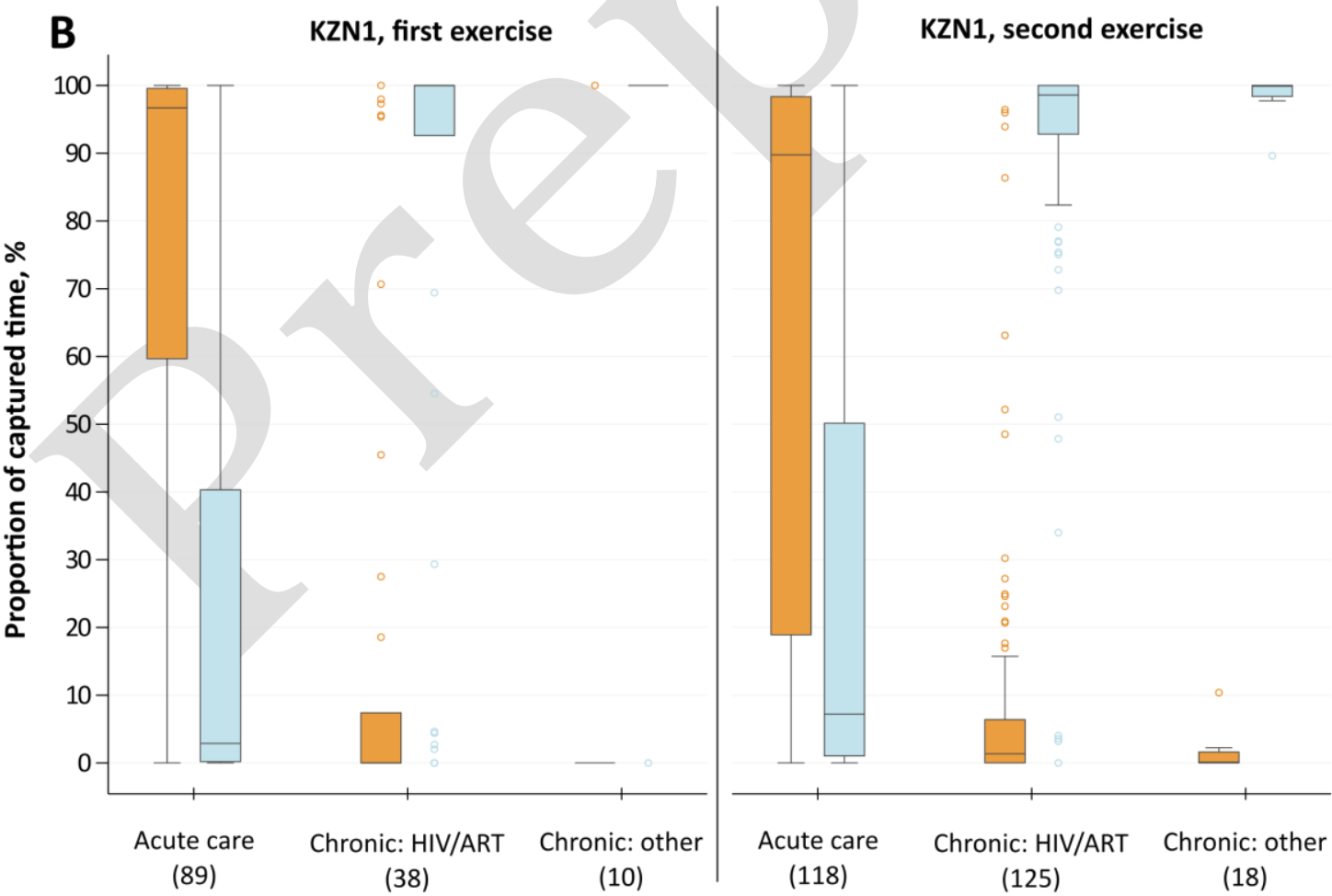

Reason for visit

( $n$ attendees) 
medRxiv preprint doi: https://doi.org/10.1101/2021.07.21.21260806; this version posted July 23,2021 . The copyright holder for this preprint (which was not certified by peer review) is the author/funder, who has granted medRxiv a license to display the preprint in perpetuity.

It is made available under a CC-BY 4.0 International license .

628 *Clinic has at least one outdoor waiting area that is part of the patient pathway.

629 Tlinic has at least one outdoor waiting area, but it is not part of the patient pathway.

630 The central horizontal line represents the median value; boxes represent the interquartile range (IQR); and whiskers

631 represent largest and smallest values within 1.5 IQR of the upper and lower quartiles, respectively. Time spent in 632 unknown locations was negligible for most clinics and is therefore not shown.

633 Panel A: Proportions are shown by clinic for all attendees at nine clinics with at least five minutes captured. Data from 634 both data collection exercises at clinic KZN1 are shown combined.

635 Panel B: Proportions are shown by self-reported reason for attendance for individuals with at least five minutes captured who were attending clinic KZN1 for the three selected reasons. ART: antiretroviral therapy; KZN: KwaZulu-Natal; TB: tuberculosis; WC: Western Cape 
medRxiv preprint doi: https://doi.org/10.1101/2021.07.21.21260806; this version posted July 23, 2021. The copyright holder for this preprint (which was not certified by peer review) is the author/funder, who has granted medRxiv a license to display the preprint in perpetuity.

It is made available under a CC-BY 4.0 International license .

Figure 2. Line graph (panel 1) and heat maps (panels 2-4) showing, respectively, total numbers of people in three indoor waiting areas and approximate occupancy density (in persons $/ \mathrm{m}^{2}$ ) of each waiting area in

\section{each of clinics KZN2, KZN6, and WC1 from 0800-1345*}

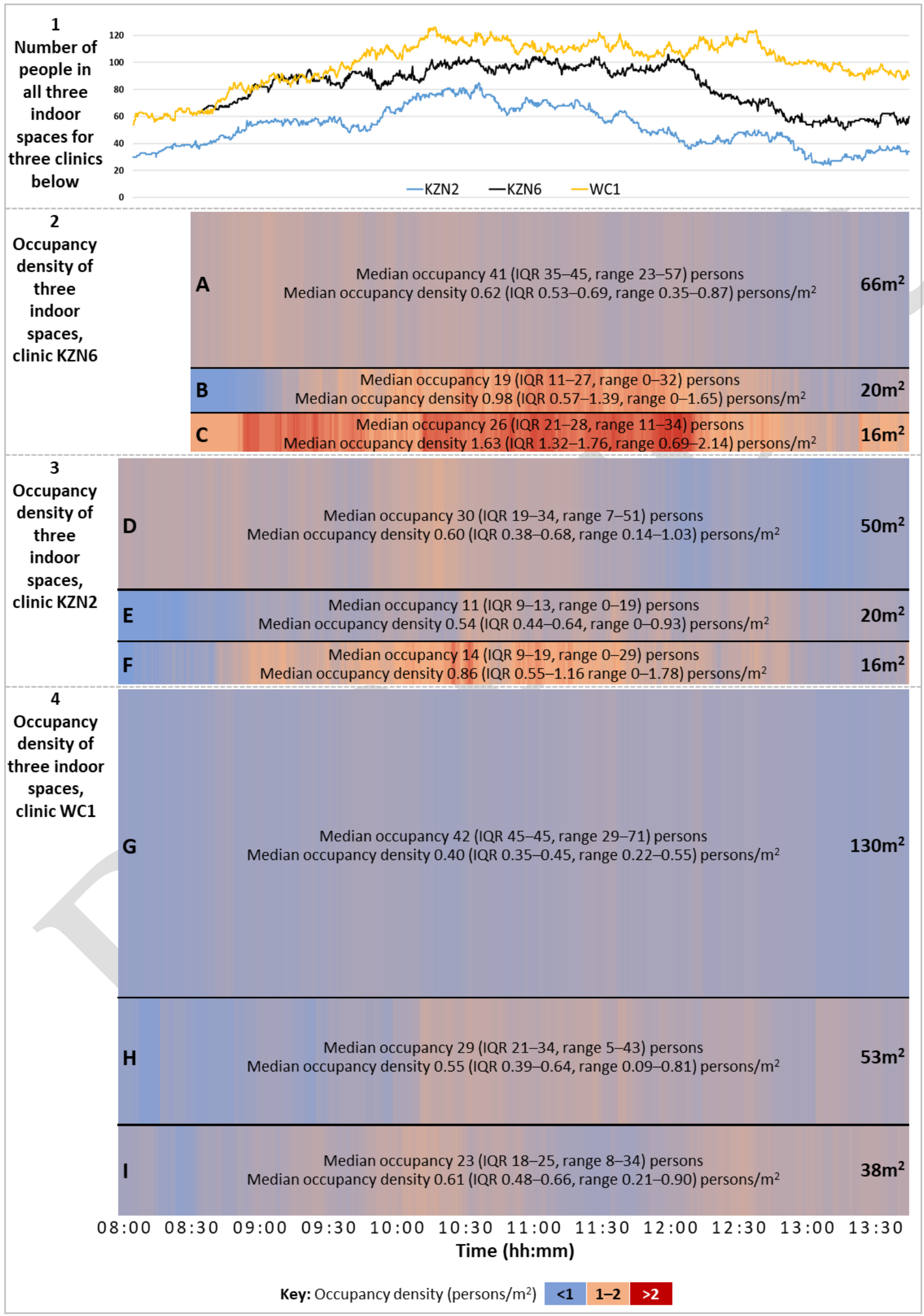


medRxiv preprint doi: https://doi.org/10.1101/2021.07.21.21260806; this version posted July 23,2021 . The copyright holder for this preprint (which was not certified by peer review) is the author/funder, who has granted medRxiv a license to display the preprint in perpetuity.

It is made available under a CC-BY 4.0 International license .

$642 *$ Data available only from 0830 for clinic KZN6.

643 Height of each row proportional to the area of the space. Each clinic was visited on a different day. See Supplementary 644 table 8 for occupancy density relative to room volume (persons $/ \mathrm{m}^{3}$ ).

645 Total numbers (line graph) indicative only of numbers of people occupying the three spaces examined, not overall 646 numbers of people in the entire clinic.

647 Spaces A, D, and G were the main (pre-filing +/- pre-vitals) formal waiting areas for their respective clinics; spaces B, C, $648 \mathrm{H}$, and I were formal (pre-vitals and/or pre-consultation) waiting areas; space $\mathrm{E}$ was a corridor used as a pre-

649 consultation waiting area; and space $\mathrm{F}$ was a combined pre-vitals waiting area, vitals administration area, and patient 650 registration area.

651 hh: hours; IQR: interquartile range; $\mathrm{mm}$ : minutes 